\title{
Fukushima Fallout: Gauging the Change in Japanese Nuclear Energy Policy
}

\author{
Elena Shadrina* \\ Graduate School of Governance Studies, Meiji University, Tokyo 101-0064, Japan
}

\begin{abstract}
The Fukushima nuclear disaster is a special case: a major twin natural disaster (earthquake and tsunami) incited a large-scale technological disaster, which resulted in a serious nuclear accident. Because the various costs are so tremendous, this triple disaster has had a pervasive impact on all aspects of life in Japan. This article describes nuclear energy policy transformation in the aftermath of the Fukushima disaster. The study draws on theoretical propositions of governance and disaster risk governance, and demonstrates that a vested interest perspective is important to understanding the results of Japan's energy policy before Fukushima. Safety, democracy, and openness were the fundamental principles of Japan's nuclear energy policy when the country decided to diversify its energy sources in the 1950s. But these basic premises were undermined by the vested interests that controlled policy administration and implementation as the nuclear energy industry developed. Analysis of Japan's recent nuclear energy policy transformation covers such dimensions as policy targets, policy issues such as safety, the fuel cycle, waste disposal, administrative structure, public awareness, and national and local policy considerations. The study identifies process deficiencies in Japan's post-Fukushima nuclear energy policy transformation and evaluates possible ways to eliminate defects through administrative reorganization and independent safety oversight.
\end{abstract}

Keywords Japan, nuclear energy policy, nuclear safety, vested interest structure

\section{Introduction}

When consideration of the policy implications of the Fukushima event began, there was a feeling among knowledgeable observers that no changes in Japan's future nuclear energy policy would occur quickly. The topic was considered too painful and sensitive to the general public, too dangerous and slippery for the career of any ranking government official or politician to receive serious immediate attention. It was clear to all that before any changes to nuclear energy policy could be made, reconciliation with the reality of nuclear energy safety and restoration of public confidence in the nuclear power industry were essential.

\footnotetext{
*E-mail: shadrina@meiji.ac.jp
}

Now, less than a year and a half after the Fukushima disaster, a critical mass of support has started to coalesce around long anticipated, but not always clearly shaped, policy reforms in nuclear energy governance. What are those noteworthy developments? In chronological order, on 14 June 2012 the Diet approved a bill establishing a new nuclear energy regulatory authority, which seizes the nuclear safety regulatory mandate from an ever powerful METI (Ministry of Economy, Trade and Industry). Another significant move took place on June 15. Amidst a domestic and international anti-nuclear outcry, the government decided to restart two reactors in Fukui Prefecture, Oi No. 3 and No. 4 reactors (Figure 1), and ordered the resumption of their operations, thereby ending a historical period of nuclear energy-free contemporary Japan.

What are the implications of these two decisions? Certainly, the combination of the two decisions turns the discussion from questioning whether Japan's future energy is nuclear to one of asking what is the future of Japanese nuclear energy. A number of programmatic documents and regulatory acts will soon reveal a more precise mode for Japan's post-Fukushima nuclear energy policy. Research attention will then begin to turn to inquiries about whether the Fukushima lessons were learnt well enough.

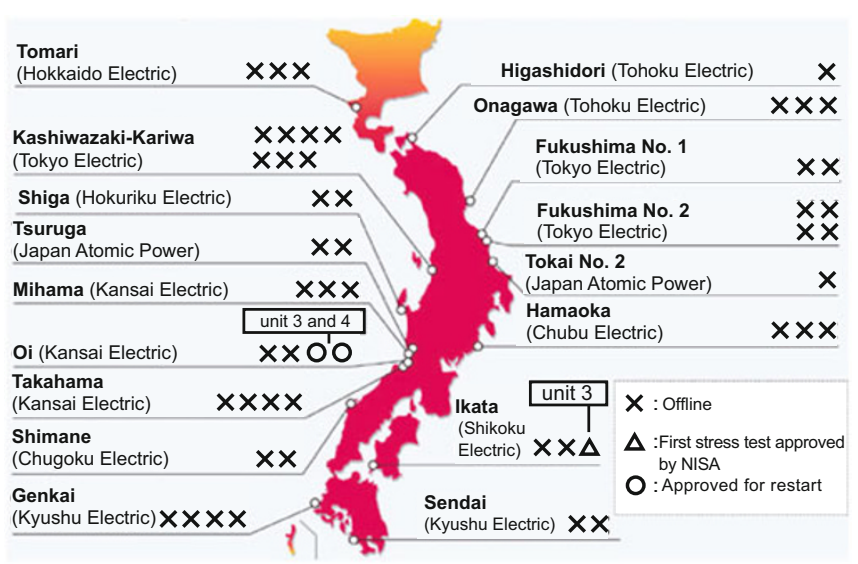

Figure 1. Operational status of nuclear reactors in Japan, as of 17 June 2012

Source: http://www.japantimes.co.jp/text/nn20120617b4.html. 
The rational expectation was that the profound traumatic experience Japan endured on and following the 11 March 2011 natural disaster would divert the nation from the path of nuclear energy development. This anticipated outcome does not conform to reality. To explain this phenomenon it is essential to analyze Japanese nuclear energy policy prior to 2011. This exploration of the roots of Japan's current nuclear energy policy draws on theoretical perspectives of governance and disaster risk governance. The concept of an embedded vested interest structure is central to understanding Japan's nuclear energy policy in the past. Vested interests have undermined the basic principles of Japan's nuclear energy policy: safety, democracy, and openness. The postFukushima nuclear energy policy transformation can be interpreted as a policy paradigm change set off by a major external shock and fostered further through a process of social learning. Given the damage associated with the dominance of vested interests in the realm of Japanese nuclear energy policy (Moe 2012), it is worthwhile to examine whether Japan's new nuclear energy policy, both as formulated and as implemented, is free from the externalities associated with previous practice. Analysis of Japan's nuclear energy policy transformation requires consideration of the targets to which policy is directed, the areas (such as safety, the open or closed nature of the fuel cycle, and so on) on which policy is focused, and the scale (national or local) at which policy debates are carried out. Potential ways to eliminate the influence of vested interests in the process of policy transformation are discussed.

\section{Theoretical Background}

The overarching concept that illuminates understanding of Japan's nuclear energy policy is governance. Two theoretical ideas are outlined: governance, focused on governance of energy in Japan, and disaster risk governance.

Government intervenes in economy, as according to Samuels (1987), for three kinds of reasons: (1) tactical (to control and maintain public law and administration); (2) strategic (to correct allocation inefficiencies and market failures); and (3) historical (to sustain historical and cultural traditions). In his comparative, cross-sectional, and historical analysis of energy sectors in industrial democracies, Samuels depicts complex interactions among market structure, centralized state power, developmental timing and finance, openness, and the nature of ruling coalitions and administrative traditions. These factors result in a commercial and competitive presence for the industrial state in the energy market place. To Samuels, electric power plays a major role in the structure of domestic markets. One of the principal conceptions underpinning Samuels' work is the politics of reciprocal consent, according to which consensual process the Japanese state acts as a guarantor to private energy businesses, “....because its power in the market place is enhanced and circumscribed simultaneously by the routines of mutual accommodation... [in which] the Japanese bureaucracy does not dominate, it negotiates. [Unlike bureaucracies elsewhere, this results in] ...the routinization of economic policy which the durability of elites and their constituencies makes possible" (Samuels 1987, 260).

In his seminal analysis of Japan's rapid post-war reconstruction, Johnson (1982) contends that industrial renaissance was a consequence of the efforts of a rational state plan, one that was determined to influence the direction and pace of economic development by directly intervening in the development process, rather than relying on the uncoordinated influence of market forces to allocate economic resources. The Japanese government established social and economic goals with which to guide the processes of development and social mobilization. Industrial reconstruction was one of these goals. An essential prerequisite for managing the developmental process was the existence of a pilot agency-MITI (Ministry of International Trade and Industry). The pilot agency was charged with task of directing the course of development itself, and employed and devised a range of policy tools to ensure that indigenous business was both nurtured and managed in the overall national interest.

Drawing on institutionalism as the overall theoretical platform for the analysis of economic policy-making, Hall distinguishes his approach from the earlier forms of institutionalism by proposing "...to consider the role of institutions located within society and the economy, as well as less formal organizational networks, in the determination of policy" (Hall 1986, 20). These tenets are elaborated further in Hall's 1993 work on changes in economic policy. Here the author adopts a state-structuralist approach to analysis of the state and incorporates a concept of social learning to examine the principal factors for policy change, major actors in a social learning process, and the relationship between social learning and the autonomy of the state. Hall defines social learning “.... as a deliberate attempt to adjust the goals or techniques of policy in response to past experiences and new information. Learning is indicated when policy changes as the result of such a process" (Hall 1993, 278). Policy changes are analyzed as regards policy instruments, instrument settings, and the hierarchy of goals behind policy, which Hall refers to as the changes of first, second, and third order. Hall maintains that first and second order changes to policy are the results of the social learning process. Drawing on Kuhn's (1962) seminal work on scientific paradigms, Hall suggests that the magnitude of third order changes invokes the change of a policy paradigm itself. Preceding his examination of three order changes, Hall states "Policy responds less directly to social and economic conditions than it does to the consequences of past policy" (Hall 1993, 277). According to Hall, policy paradigms are strong and influential in policy-making and, in particular, in the areas involving "highly technical issues as well as a body of specialized knowledge," such as energy policy (Hall 1993, 291). 
Understanding of Japan's model of economic governance would be incomplete if its traditional practices are excluded from the analysis. In an analysis of amakudari, ${ }^{\text {i Colignon }}$ and Usui (2003) hold that one of the reasons amakudari survives is because the central bureaucracy needs it. More concretely, as the central bureaucracy is small, many projects are outsourced to the local governments, which create sectionalism among the central ministries. Importantly, the central bureaucracy emphasises the use of industry associations and public corporations for specific projects instead of expanding existing ministries. MITI/METI is known for actively seeking advice from large business entities and even requiring such an interaction on a near-constant basis (Yergin and Stanislaw 2002).

Given the importance of local perspectives in Japanese energy policy-making, reference is needed to the excellent analysis of issues relating to the siting of nuclear facilities developed by Lesbirel $(1990,1998)$. Drawing on the concepts of conflict, bargaining, and compensation as the means to resolve environmental disputes, Lesbirel notes that Japanese energy siting history highlights diversity in the structure of bargaining environments, power relationships, and the effectiveness of conflict resolution mechanisms. His analysis of energy siting processes and outcomes suggests that "in siting, negotiators and leaders often respond to changed circumstances and develop innovative approaches and strategies to deal with political siting problems... [and goes on to say that], "Japanese leaders and negotiators... often work privately behind the scenes... [where] they do develop sophisticated strategies for dealing with highly complex conflictual situation" (Lesbiel 1998, 151-52).

Linking three levels of energy policy-making is the concept of vested interests, which is actively employed in the analysis of the contemporary Japanese nuclear energy policy (DeWit 2011b; DeWit and Kaneko 2011). Work by Moe (2012) is of particular interest for the analysis of the postFukushima energy policy. This recent work on the Japanese renewable energy policy elaborates the author's propositions made in his earlier volume (Moe 2007). Drawing on Schumpeter's (1983) evolutionary economics where structural economic change - the key element to long-term economic growth and development - is described through the changes in the role of, and relationship between, technology and institutions, and Olson's (1982) notion of interest groups and vested interests, which resist any kind of structural change, Moe (2007) proposes that in order to enable the destruction of old inefficient industries and promote potentially promising industries the role of the state "is to ensure that no vested interests become so powerful and influential that they can effectively block the process of creative destruction." ${ }^{\text {'ii }}$ According to Moe (2007, 23), "political consensus and/or social cohesion in people make it easier to promote structural economic change, that is, making decisions that are in the interest of society at large, going against those of vested interests."To be sure, one of the strongest impacts of the Fukushima event is the marked increase in theoretical and empirical research in the area of disaster risk governance.
Within the body of literature on March 2011 catastrophe, there are works detailing geological and seismological specifics of the 2011 Tohoku Earthquake and Tsunami (Norio et al. 2011) and characterizing parameters of the nuclear crisis (Sciubba 2011; Funabashi and Kitazawa 2012). These studies help the reader grasp the scale of the disaster (often called the triple disaster) that Japan faced. Another important contribution of this class of studies is the creation of awareness that there is no room for thinking that something is "unthinkable" when it comes to nature. Similarly the belief that "absolute safety" is attainable is proven to be an absolute myth. These studies establish the conviction that society must be fully prepared for multifaceted, complex, and cascading disasters. Within this trend exist interdisciplinary approaches that transform disaster risk management, which tends to treat technical, economical, social, sociological, and psychological aspects separately, into disaster risk governance, which includes risk assessment, management, and communication as the key elements of comprehensive framework of governance (Lim 2011). Furthermore, escalating environmental change demands integrated disaster risk governance as the only approach that equips modern society against the increasing number and impact of disasters (Shi et al. 2010; Jaeger 2010). Although relatively new as an area of knowledge, disaster risk governance has evolved to embrace innovative approaches to technology, communication, scale of policy implementation (Ikeda and Nagasaka 2011), and organizational structure (Aoki 2010; Aoki and Rothwell 2011).

Disaster risk theory addresses such questions as the extent of disaster risk governability (Kasperson 2010; Jaeger 2010), and the governance techniques needed to protect populations and places especially vulnerable to disasters, but which at the same time are most needed when the disaster strikes assets, such as critical infrastructure (Fekete 2011). There is nonetheless a growing concern that mushrooming theoretical insights are largely disregarded by the policy makers and practitioners and that an attempt to bridge the gap between science and decision making through the identification of the tasks for overcoming this tension is required (Kasperson 2010). This study investigates the flaws of the Japanese nuclear energy policy as revealed by the 11 March 2011 natural disaster and nuclear accident. It identifies the dimensions of Japan's nuclear energy policy transformation, assesses the deficiencies in the process of transformation, and outlines possible ways to eliminate deficiencies and improve safety and accountability.

\section{Japan's Nuclear Energy Policy Before 2011}

Three main arguments used to promote nuclear energy in Japan. The first stressed the notion of energy security. The two other principal considerations emphasized economic costs and benefits and environment. Together, these three perceived positive features of nuclear energy are often referred to as the "3E." 
Japan possesses a very limited stock of domestically available natural resources. Despite being one of the world's most developed economies, Japan is the world's third largest importer of oil and the largest importer of liquefied natural gas (LNG) and coal. Japan's self-sufficiency in energy is very low. Indigenous energy sources (including nuclear energy) provide only 18 percent of its energy consumption. If nuclear energy is excluded, 96 percent of its energy is derived from imported sources. Logically, the nuclear energy option represented an effective means by which to diversify Japan's sources of energy, thereby improving national energy security.

Speaking in economic terms, the cost of a unit of electricity generated at a nuclear power plant (NPP) was estimated as the lowest when compared with the cost of electricity produced using any other traditional or renewable source of energy (Matsuo, Nagatomi, and Murakami 2011). For the economy striving to maintain its international competitiveness, production cost is a considerable issue. Although the number of proponents of the nuclear energy cost-efficiency argument has declined considerably after the price of the Fukushima accident became known, there is still some support for nuclear energy based upon this very economic reasoning. Less controversial point is that the nuclear energy helped Japan reduce the burden of fossil fuels imports. It is estimated, for instance, that because of nuclear power, Japan's oil imports were lower by some 440 million barrels a year. This aspect gains additional importance in the light of Japan's deteriorating public finance and trade balance deficit posted in 2011 for the first time over the last three decades.

On the environmental front, Japan has responsibility to abide by its earlier commitments on the climate change policy. For the economy with already advanced levels of energy-efficiency, it is a challenging task to pursue the economic growth while toughening the climate policy parameters. Reliance on nuclear power, which had been viewed as rather ecologically clean option, seemed a practical solution. According to the Federation of Electric Power Companies (FEPC), for instance, nuclear power helped Japan lessen its annual $\mathrm{CO}_{2}$ emissions by some 14 percent.

\subsection{History of Japan's Nuclear Energy and Policy}

By 11 March 2011 Japan had one of the world's most advanced commercial nuclear power programs. The nuclear power industry consisted of 54 reactors with the total installed generating capacity of around $49 \mathrm{GW}$. This made Japan the third largest (after the United States and France) nuclear power generator. Additionally, Japan had two reactors under construction and 12 others at different planning stages.

The Japanese electric power industry was private from its outset in 1882. It was only before World War II that the government imposed greater control over the sector (1938) and partially nationalized the industry (1942-1951). Private business also dominated the nuclear energy sector, where competition developed between two interest groups with poorly compatible interests: scientific, which was in favor of the development of domestic technology and was led by the scientific establishment; and commercial, which relied upon imported technology and was led by the government, organized business, and technocratically minded scientists. The history of nuclear development can be divided into six periods: (1) military development (1939-1945); (2) prohibition (1945-1953); (3) institutionalization (1954-1965); (4) take-off (1966-1979); (5) steady expansion and privatization (1980-1994); and (6) general stagnation and decline of plutonium breeding from 1995 to the present (Yoshioka 1999).

Thus, Japan started its modern nuclear research program in 1954 (Yoshioka 2005, 2006). ${ }^{i i i}$ The Atomic Energy Basic Act was introduced in 1955, Article 2 of which says, "The research, development and utilization of nuclear energy shall be limited to peaceful purposes, shall aim at ensuring safety, and shall be performed independently under democratic administration, and the results obtained shall be made public so as to actively contribute to international cooperation" (Nuclear Safety Commission 1955). ${ }^{\text {iv }}$ In 1956, the Japan Atomic Energy Commission (JAEC) was established. Key governmental agencies and industry began to develop a closed nuclear fuel cycle through reprocessing and recycling the used nuclear fuel from light water reactors (LWR). In so doing, Japan hoped to decrease dependency on foreign resources. Japan's commitment to closing the nuclear fuel cycle necessitated the development of certain technologies, such as the fast breeder reactor (FBR) and reprocessing to produce the fuel for use in these reactors. The adherence to reprocessing subsequently locked Japan into the need for FBRs in order to prevent the stockpiling of the reprocessed material — plutonium - a material usable for nuclear weapons production and therefore subject to stringent safeguards. This strategy has engaged Japan in a technological path with dubious economic and safety benefits.

On this account, Yoshioka (1999) attributes the path Japan has followed to the competition between two groups: MITI and the private sector and the Science and Technology Agency (STA) aligned with public research corporations such as the Japan Atomic Energy Research Institute (JAERI). The MITI group targeted gradual expansion of the commercial nuclear enterprise, mainly by importing US reactors. The STA group's mission was to promote domestic research and development, particularly of its own FBR. Japan's adherence to the FBR program (while many other countries abandoned it) is also explained through this very dualistic structure of competing interests. Depicting the STA's motivation, Yoshioka points out that in a situation of uncertainty surrounding the space program, the STA attempted to maintain its domestic influence with the scientific community by promoting the FBR program.

As a consequence of the 1973 oil crisis, Japan became committed to developing nuclear energy. The Three Laws for Electric Power Resources Sites (Dengen Sanpou), namely, the Law for the Adjustment of Areas Adjacent to PowerGenerating Facilities, the Electric Power Development 
Promotion Tax Law, and the Special Account Law for Electric Power Promotion were adopted in 1974. Together, these documents contributed to nuclear power regulatory framework and were especially instrumental in facilitating the siting of new NPPs. After 2000, increasing prices for fossil fuels and climate change policy targets have provided the most serious arguments in favor of nuclear energy. In March 2002, the Japanese government announced that it would increase its reliance on nuclear energy to achieve greenhouse gas emission reduction goals set by the Kyoto Protocol. In 2008, in the Cool Earth-Innovative Energy Technology Program (METI 2008), the JAEC planned a 54 percent reduction in $\mathrm{CO}_{2}$ emissions (from 2000 levels) by 2050, targeting a 90 percent reduction by 2100 . This envisioned that nuclear energy would contribute about 60 percent of primary energy in 2100 (compared with 10 percent at the time the plan was formulated). By March 2011, Japan had about 32 percent of electricity generated by NPPs and planned to increase this share to some 50 percent by 2030 through the construction of 14 new reactors (JAEC 2009).

Japan had a clear focus on nuclear power stating the four main objectives of the nuclear energy policy as follows: (1) increase nuclear power capacity as a major element of electricity production; (2) advance domestic recycling and reprocessing; (3) develop reactors designs in order to improve the utilization of fuel; and (4) promote nuclear energy to the public by emphasizing its safety.

\subsection{Institutional Framework for Nuclear Power Regulation}

Examination of nuclear policy-making in Japan demands a three-level analysis: regional, national, and international. National and regional aspects are addressed below, while only a few points involved with the international facet of nuclear policy-making in Japan are touched upon.

Since its establishment, nuclear energy policy in Japan was generated by the governmental agencies and implemented by the electric power industry actors and a number of publicprivate institutions (Figure 2). The Japan Atomic Energy Commission, under the authority of the Prime Minister's Office, sets national nuclear policy (The Long-Term Program for the Development and Utilization of Nuclear Energy, LTP), and promotes research, development, and implementation of nuclear energy. The Nuclear Safety Commission (NSC), a more senior government body set up in 1978 under the Atomic Energy Basic Act, was responsible for formulating policy together with JAEC until the NSC disappeared from the scene in 2012. MITI (reorganized into METI in 2001) focused on the promotion of industrial policy, including nuclear policy. MITI prepared the Long-Term Energy Supply and Demand Outlook (choki enerugii jukyu mitoshi) and worked with the nuclear power industry to facilitate the implementation of JAEC's LTP. The Nuclear and Industrial Safety Agency (NISA) within the MITI/METI has been responsible for nuclear power regulation, licensing, and safety; it also conducted regular inspections of safety-related aspects of all nuclear power plants. Gradually, MITI expanded its influence on the matters of nuclear safety (Box 1), leaving the NSC to only review its actions. Also, MITI eventually gained control over a portion of the research and development of nuclear power that had been the STA's realm; the STAv has effectively become a bureaucratic advisory board.

The Ministry of Culture, Sports, Science and Technology (MEXT), the Ministry of Foreign Affairs (MOFA) and the Ministry of Finance (MOF) also played their respective parts in the development of nuclear power. The MOFA, given the involvement of the United States and other countries in Japan's nuclear sector development, often negotiated critical agreements to ensure the progress of the Japanese nuclear industry. Meanwhile, the MOF was crucial in funding the new projects.

Regional projections of nuclear energy policy are mainly related to the NPPs' siting. In the affairs such as land use, the Ministry of Land, Infrastructure and Tourism, Ministry of Agriculture, Forestry and Fisheries, and Ministry of Internal Affairs and Communications are those possessing important jurisdiction. On the international scene, throughout the 1990s the construction of NPPs was additionally facilitated by Japan's compliance with provisions of the US-Japan Structural Impediment Initiative. The latter imposed on Japan the obligation to expand its public investment, thereby confining the influence of the Japanese yen to the domestic market and preventing the devaluation of the US dollar.

\subsection{Nuclear Power Politics- the Vested Interests in Japanese Clothes}

Japanese politicians and parties are known to be less potent than Japan's administrative bureaucracy, which primarily determines government policy. This is largely a result of one party - the LDP (Liberal Democratic Party) - dominance for nearly 40 years after 1955 . Under the LDP, bureaucrats could produce any necessary political decision. While there are still the signs that many LDP Members of Parliament continue to represent the vested interests of particular industrial groups, including the power generating sector, the positions of other political parties and independent politicians regarding nuclear energy began to diverge into pro- and anti-nuclear stances (Jupesta and Suwa 2012). ${ }^{\text {vi }}$ But energy politics is known for being not only a result of official and formally established settings (Wang and Chen 2012). There is a web of implicit threads woven into a fabric of nuclear energy politics. A network involved with the promotion of nuclear power, a camp revering its unwritten rules, is known as a "nuclear village," or genshiryoku mura, in Japanese.

Traditionally, Japanese nuclear policy makers and the nuclear industry have been interconnected through an elaborate system of rituals. An implicit process of subtle negotiations and discussions involving the key actors prior to their official meeting, nemawashi (literally, "digging around the roots of a tree" before transplanting), is intended to produce 


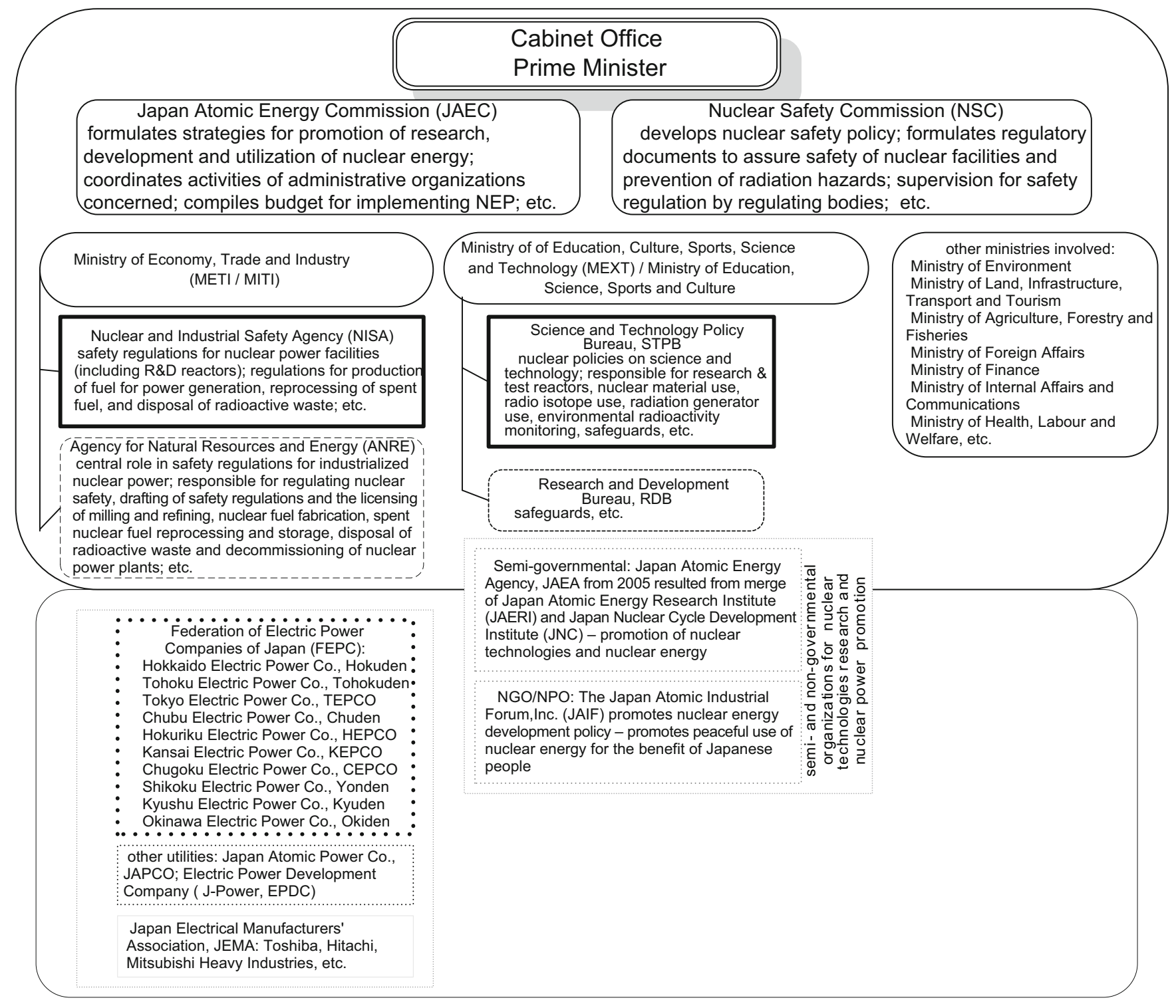

Figure 2. Organization chart of Japan's nuclear power sector

an invariable consensus even in the case of persistent conflicts of interest. Although for the agencies assigned with one task it could probably be a commendable practice, in case of nuclear policy-making this tradition has caused great damage (see Boxes 2 and 3). That is, in the area of energy planning, the principal objectives and targets for energy policy in the METI's Long-Term Energy Supply and Demand Outlook would customarily converge with those in the JAEC's LTP for nuclear energy development. In nuclear energy safety regulation, the JAEC and the STA would downplay safety considerations after consultations with the METI. In matters of financial backing, the MOF would allot the funding for domestic research on and development of the same technologies that were readily available overseas. Flaws in administrative and regulatory routine would reproduce themselves in a new round of staff rotation among and between various "districts" of the nuclear village.
Among the most notorious practices embedded in Japanese nuclear energy policy- making are amakudari (descent from heaven) and amaagari (accent to heaven), an illegal revolving door between the Japanese government and corporations (Wang and Chen 2012). The practice is hard to stop despite severe criticism from within and outside of the government and the government's own regular pledges to weed it out. Since 2000, the power companies have sent at least 100 employees to central government bodies, in particular to the NSC and other offices involved in safety at NPPs. TEPCO, which has sent 32 workers to the government, had reserved seats at several positions. By the same token, 68 former industry ministry officials with extensive nuclear industry oversight roles have moved to postretirement jobs as executive board members or advisers at 12 of the major power companies over the past five decades. As of 2 May 2011, there were still 13 of these former ministry officials 


\section{Box 1. METI Grows Stronger}

After reorganization in 2001, the new METI continued to implement energy policy on nuclear, fossil, and renewable sources. METI obtained a broader jurisdiction through taking charge of the experimental nuclear fuel cycle programs (including the controversial reprocessing plant and newly proposed MOX (mixed oxide) fuel fabrication plant in Rokkasho, Aomori). The former STA has been amalgamated, together with the former Ministry of Education and Culture, into the new MEXT, which no longer administers the FBR projects (Monju and others) or Rokkasho Nuclear Fuel Cycle facilities. Authority for all of these has been shifted to the new METI. The JAEC became a formal part of the new Cabinet Office, which was an expansion of the former Prime Minister's Office, while the safety regulation bureaus previously attached to STA and MITI were unified under the new label of Atomic Safety Bureau, which was annexed to METI. This bureau had 633 staff members, nearly doubled those of its STA and MITI predecessors. The newly established Ministry of Environment had a modest role over nuclear issues. Environmental assessment procedure for nuclear power stations was almost entirely under the jurisdiction of METI. The country's aggressive plutonium burning program in existing uranium reactors (known as "plu-thermal" program) was totally taken over by the METI administration (Figure 3).

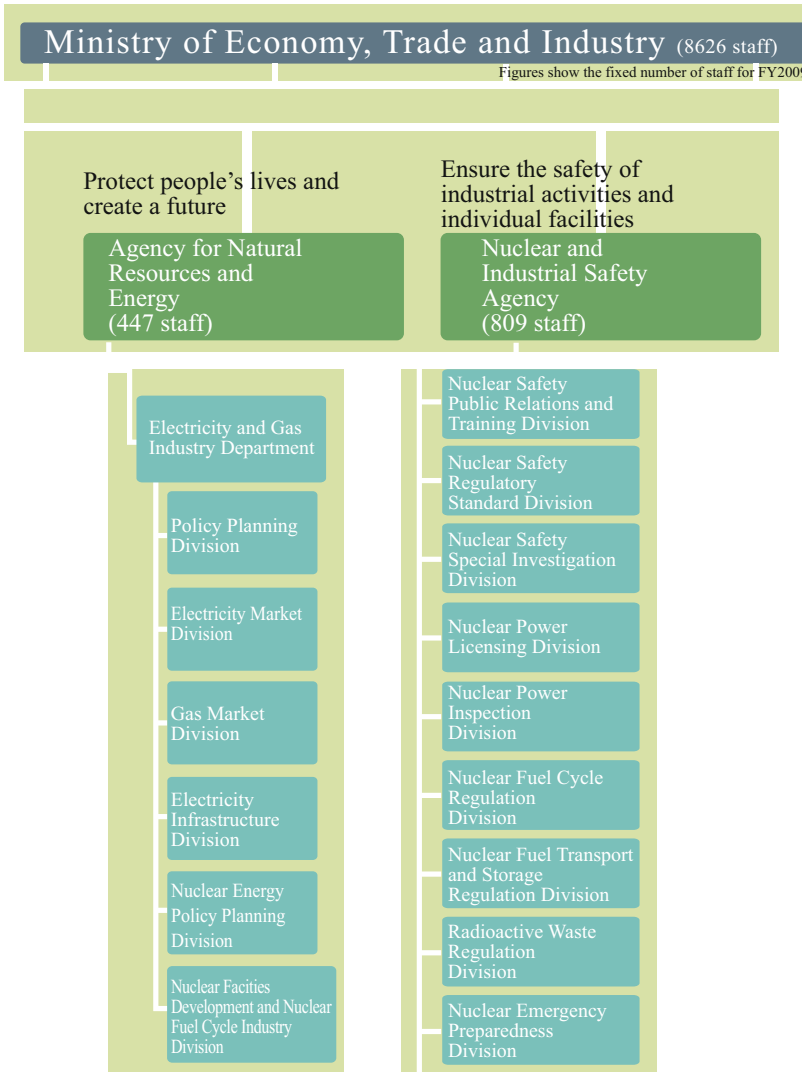

Figure 3. Departments of METI involved with nuclear energy policy planning and nuclear energy safety regulation

Source: Adopted from METI's organizational structure chart at http://www. meti.go.jp/english/aboutmeti/data/aOrganizatione/pdf/chart2009.pdf.

working at TEPCO and 10 ensconced at other power companies (The Yomiuri Shimbun 2011).

Another pattern of close relationship between the government and industry is nigen taisei, ${ }^{\mathrm{vii}}$ a complex relationship

\section{Box 2. Records on Safety Management}

Since the 1990s, due to a series of accidents and scandals, there has been a deepening public concern about the safety of nuclear power in Japan. The accidents were at the Monju FBR in 1995 and at the reprocessing plant at Tokai-mura in 1997 and again in 1999.

In 2002, a scandal erupted over the documentation of equipment inspections at TEPCO's (Tokyo Electric Power Co.) reactors. In August 2002, the government revealed that TEPCO was guilty of false reporting in routine inspections of its nuclear plants and systematic concealment of plant safety incidents. After the reactors were shut down for inspection, the utility admitted two hundred occasions of the submission of false technical data to the authorities between 1977 and 2002.

In 2004, an eruption of heated steam from a burst pipe at a reactor run by Kansai Electric killed five workers. An investigation showed this pipe section was omitted from safety checklists and therefore has never been inspected since the plant started its operation.

In 2007, NISA ordered the reactor owners to check their records and uncover the incidents that should have been reported at the time but were not. This revealed other TEPCO's accidents that were not reported in 2002. TEPCO reported about its Fukushima I-3 BWRs' (boiling water reactors) criticality incident that lasted over seven hours during an outage in 1978, when control rods slipped out of position, and at least six emergency stoppages at Dai-Ichi. Kansai Electric Power Co., Chubu Electric Power Co., Tohoku Electric Power Co. and Hokuriku Electric Power Co. also admitted to having submitted faked safety records.

Also, multiple falsifications by the utilities' sub-contractors were disclosed. One such, for instance, was a cover-up case in a production process of a USD 250 million worth steel pressure vessel for TEPCO in 1975. Scrapping the damaged vessel, as the law required, would mean Hitachi's bankruptcy. The vessel was eventually reshaped to cover the damage (it held the fuel rods in the core of the No. 4 reactor at Fukushima's Dai-Ichi plant). Mitsuhiko Tanaka, who supervised the work at the time, filed a report on the case years after the Chernobyl accident. However, summoned to clarify the case, Hitachi denied any misdoings and the government did not initiate further investigations.

where the government has no choice but rely on the industry for the implementation of the ministry's plan. In turn, the government has no independent assurance that industry abides by the government's plan. When conflicts of interest arise, they are resolved within the policy-making system, most of the time through the government's splendid offerings in the form of subsidies or some other sort of favored treatment. Under this practice, for instance, METI has implemented the Monju FBR project in Tsuruga. Rokkasho-mura reprocessing plant also exemplifies this point. Recently, the continuation of nigen taisei has become increasingly difficult because of its sheer contradiction to the government's and METI's own declarations about the electric power market deregulation. Moreover, growing costs of reprocessing fuel and overall deteriorating economics of nuclear power in Japan have affected the sector's attractiveness. It has grown more difficult for the government to get the industry engaged in the implementation of the plans it charts. 


\section{Box 3. Records on Risk Management}

One of the major natural hazards in Japan is earthquakes. High seismicity demands a particular attention to design and construction of NPP. In May 2007, revised seismic criteria were announced ordering the reinforcement of older plants. In July 2007, the Niigata Chuetsu Oki earthquake occurred on a fault close to the Kashiwazaki-Kariwa NPP. Although there was no damage to the main parts of the plant, some leakage of radioactive water occurred. The investigation committee acknowledged that the government was responsible for approving construction of the first units in the 1970s in dangerous proximity to a geological fault line.

Tsunami is another feature of Japan. Since 1498, there have been 16 tsunamis whose wave heights exceeded $10 \mathrm{~m}$. These events happened on average once every 30 years. As the Fukushima accident showed, although a new inspection system of nuclear facilities came into effect in 2009, the utilities undertook no preventive measures. TEPCO's Fukushima NPP operated on the assumption that the maximum height of a tsunami was $5.7 \mathrm{~m}$, although only a few days before the March 11 tsunami TEPCO submitted a report that admitted the possibility of a tsunami wave height of up to $10.2 \mathrm{~m}$. Interestingly, at the time of the NPP construction, TEPCO lowered the coastal cliff level by $25 \mathrm{~m}$ to make it easier to deliver the construction materials by the sea. While TEPCO called the $13.1 \mathrm{~m}$ tsunami that hit Dai-Ichi "unforeseeable," the results of geological surveys in recent decades suggested otherwise. From 1980, there were findings that the area was hit by three giant tsunamis (Minoura and Nakaya 1991). The industry has been systematically neglecting the warnings based on advances in seismology (Ishibashi 2007).

Yet, old habits die hard. It has recently been revealed that more than 20 secret meetings between the officials from the JAEC (Monju operator), the Cabinet Office, METI (ANRE), MEXT, Japan Nuclear Fuel Ltd., JNFL (Rokkasho operator), the Federation of Electric Power Companies of Japan, and the representatives of the electric power industry were held through the end of April 2012. The government's panel on basic policy for nuclear energy power headed by JAEC has been behind these "study meetings," which "coincidentally" have convened the promoters of nuclear power exclusively. The prime agenda of those closed-door meetings was to produce recommendations for a concurrent approach to reprocessing and direct disposal of spent nuclear fuel, which could help the Rokkasho fuel reprocessing plant survive. Premeeting preparations were sufficiently advanced that even a full draft of a report on nuclear fuel cycle policy options was disseminated among the attendees. The Japanese media spurred severe public criticism of the old-fashioned decision making on such a critical issue and the panel was forced to announce the suspension of its work.

Turning to yet another level of policy-making-local communities - these settings are one of the more important loci for the determination of nuclear energy policy. Initially, the Three Laws' provisions ensured national subsidies for those local governments that accepted an electric power plant, especially when a NPP was proposed for construction in their jurisdiction. Not only the subsidies provided for the first 5 years after the start of the NPP construction were an alluring lever. Local governments were additionally guaranteed receipt of local property tax paid by a NPP. Japanese local governments are known for their outstandingly large budgets. This might suggest a somewhat equal scale of significance between local and regional governments in the politics and economics of Japan. In practice, local governments are not as autonomous or important. San-wari jichi (30 percent autonomy) is a system where about 70 percent of a local budget's expenditure is composed by the transfers from the central government. This sum, however, comes with some strings attached (himotsuki), which makes the central government and the local governments inseparable (Onitsuka 2012). This sort of relationship to a certain degree has contributed to the progress of nuclear power in Japan.

\section{Box 4. Nuclear Power Siting}

In the immediate aftermath of World War II, the government was concerned about the means to revive devastated areas as well as bring growth to rural Japan. Local development was often connected with NPP construction. After Oukuma town in Fukushima Prefecture, for instance, accepted TEPCO's deal, its 1979 budget soared to 22.6 times the 1965 amount with the revenues related to the NPP accounting for as much as 88.5 percent of a total amount of tax revenues (Onitsuka 2012). This dependence has boded ill, however, for many of the communities who accepted the deal. An unfortunate consequence often involved creating an infrastructure and employment that could not be sustained without continued subsidy. For instance, Futaba decided to invite the construction of two more reactors in 1991, because their budget was exhausted and could no longer cover even the maintenance of the public facilities built in the first years of the nuclear revenue bonanza. Local communities often found themselves locked in a vicious circle: having opted to host a NPP, they developed a subsidy dependence and needed more reactors to keep their budgets balanced. Nuclear power addiction (genpatsu izon-shou) has become common.

The negotiation routinely involved the central and local government representatives (often governors, but also local government officials, fishing and agricultural cooperatives, and other interest groups) and industry (utilities). The governor has the ultimate power to veto a project regardless of the progress already achieved through negotiation with all other parties concerned. There were only a few cases when the local community called for a referendum and could influence the decision (Lesbirel 1998). Overall, the construction of NPPs has been relatively easy thanks to such Japanese features as a hierarchical social structure (a land lord possessing large piece of land could play a decisive part in striking a siting deal), a lack of transparency, rivalry between the communities, poverty in peripheral areas, and other special variables unrelated to nuclear plant design, safety, or location.

Siting a nuclear facility has been a bargaining process where costs and benefits were evaluated by the sides involved, often leading to "creative solutions and very different political outcomes" (Lesbiel 1998, 19). On the face of it, facility siting has often enabled the government, utilities, and local communities to reach a satisfying compensation deal, the positive impact of which often spread into areas adjacent to the NPP site (donut effect phenomenon). 


\section{Nuclear Energy after Fukushima}

\subsection{Nuclear Energy Policy Framework}

Since 11 March 2011, the Japanese government has faced numerous contingencies in the area of electricity supply. Japan's energy policy stands to undergo a profound transition to cover a 30 percent chunk of electricity previously generated by NPPs. The principal decision to make is about the future of nuclear energy in Japan. Currently, the government is considering several scenarios for the ratio of nucleargenerated electricity in the total supply by 2030 . The options, as a percentage of Japan's total power supply, are: zero; 15 percent; or between 20 and 25 percent. This decision certainly deserves most careful consideration.

Overall, the system of energy policy-making in Japan needs a reform away from a mode that caters to vested interests and toward a more transparent and socially fair policy. The changes involve diverse aspects and are centered on enforcement of energy safety, improvement of the economics of energy, and protection of the environment. Currently, Japan lives under the three-year Action Plan for Energy Supply-Demand Stabilization. The prime concern of the government is to develop and implement policies in order to avoid electricity shortages and prevent steep rises in energy tariffs. Power-saving measures (setsuden) are imposed on the corporate sector and households for the second summer to make up for the supply deficit ranging from 14.9 percent for KEPCO, 2.2 percent for Kyushu Electric, and 1.9 percent for Hokkaido Electric consumers (Kanashima 2012). This certainly endangers Japan's economic recovery. Although in the first quarter of 2012 GDP growth was reported at 1 percent (with an annualized rate of 4.1 percent), the Japanese economy currently is being kept afloat largely thanks to government expenditures to revive the disaster hit areas.

In October 2011, the government published the White Paper on Energy Policy (METI 2011), confirming that in the medium- to long-range future Japan's dependency on nuclear energy will be reduced as much as possible. The document analyzes the weaknesses of the domestic energy system and reflects on relevant practices outside of Japan, such as renewable energy policy in the EU and United States and growing energy demand of China, India, and other countries. The document states that a new energy policy is to be introduced in summer 2012. The basic principles of energy policy set forth by the Energy and Environment Council inform the platform for a new energy policy, where considerations of safety (reduction of nuclear power use), efficiency (cost-efficient energy mix), and environment (commitment to climate change policy) are given top priority. Based on these principles, the JAEC in coordination with other concerned entities is expected to present a new nuclear energy policy (National Policy Unit 2011). Additionally, the Energy and Environment Council is tasked with the development of the Innovative Strategy for Energy and the Environment.

\subsection{Organizational Restructuring}

Under the nuclear safety regulatory reform, a number of organizational changes are envisioned (METI 2012). The government has eventually started to tackle the paradoxical status of METI within the national system of nuclear policy-making. Confusion often occurred over METI's authentic role in nuclear energy policy: is it a promoter or a regulator of the nuclear sector? It has been criticized elsewhere (DeWit 2011a, 2011b; Matanle 2011; Moe 2012) that as a renowned heavyweight, who crafted Japan's industrial might, METI (MITI, formerly) has been directly involved with nuclear regulation for the purpose of utilizing technological advancements in the nuclear sector to trigger the development of the Japanese economy's other segments. Most of the critiques contend that it is hard to expect the agency whose mandate is to promote the industry to act as an impartial safety watchdog. It also has been pointed out (Funabashi and Kitazawa 2012) that significant harm was caused by placing NISA, an administrative body tasked to regulate nuclear power safety, under the METI umbrella. The ongoing structural reform aims to separate nuclear regulation from nuclear promotion and centralize regulatory duties into one agency.

Following Fukushima, a temporary viii regulatory system has been established that requires the utilities to report the results of two-stage stress tests to NISA. Then the NSC verifies NISA's findings. If a reactor's safety is certified, the ministers involved discuss the decision and hold talks with the local political leaders of the areas hosting the nuclear facility in question. As of June 2012, NISA received firststage reports on 22 reactors (including the two Oi units and one Ikata reactor), but NSC has stopped reviewing the agency's reports after the Oi tests expecting a new watchdog to take over (Nagata 2012).

On 31 January 2012, the Cabinet adopted a bill envisaging several steps in the direction of safety regulation reorganization (METI 2012). The document calls for creation of a special nuclear safety agency, which would be established as an external organ of the Ministry of Environment (MOE) by separating the nuclear safety regulation section of NISA from METI and unifying relevant functions of other ministries. The new nuclear regulatory agency, the Nuclear Regulatory Authority (NRA), was expected to be set up by April 2012, but the Diet's panel investigating the Fukushima accident adopted a tougher stance with regard to the agency's status (The Japan Times 2012a).There has been public discussion and debate in the Diet about the status of the new nuclear safety regulatory body (JAIF 2012). The main issue is whether or not the NRA should be established as a ministerial level agency unifying all safety regulatory activities currently excecuted by various ministries/agencies (provision of Article 3 of The National Government Organization Law) or a council/committee type unit set up within the Cabinet Office under Article 8 (The National Government 1948; JAIF 2012). Finally, on 20 June 2012, the Diet enacted a law to establish the NRA (under Article 3) from September 2012 (Figure 4). 
Under the new system, the NSC and NISA will be abolished. The former proved to be almost useless in advising the government during the hardest period of the Fukushima crisis, while the latter was too intractably involved with promotion of nuclear commerce and too ineffectual in its control of nuclear safety activity. Both not only had institutional and organizational deficiencies, but also were rather poorly staffed and incapable of providing expert opinion and guidance on the contingencies of Fukushima.

In the future, the NRA will have its own independent staff of 495 (mainly consisting of former NISA and MEXT officers) and a budget of 50 billion yen (about USD 611 million). Organizationally, the NRA and the Nuclear Safety Investigation Committee (NSIC) will operate administratively under the auspices of the Ministry of Environment (MOE). The NRA's main office will be organized under a DirectorGeneral for Emergency Response Measures, a DirectorGeneral for Residents Crisis Management, and a section for crisis management. Also, regional emergency preparedness will be reinforced through Nuclear Safety Inspectors' Offices, Regional Nuclear Safety Contact Officers will be dispatched to nuclear facilities hosting prefectures, and Environment and Nuclear Safety Divisions will be created in each Local Environment Office. The structure and function of the Nuclear Emergency Response Headquarters will be enhanced. The NRA is expected to act independently; its top official, the NRA commissioner, will have the authority to make an administrative decision on nuclear safety regulation, appoint and dismiss officials, make recommendations to relevant government organizations to ensure nuclear safety, and draw on an independent account in the national budget. Regulatory and safety-related functions previously implemented by other ministries, such as regulation of research reactors, environmental radiation monitoring, radiation protection in emergencies, and matters relating to nuclear security will be united in NRA. Crisis management is expected to be one of the most important roles of the NRA.

To ensure the new agency's independence from any governmental body in charge of nuclear power promotion, a "no return rule" will be enforced in the agency's staffing policy. This rule means that top senior officials who join the new agency on loan from METI/NISA and MEXT will not be allowed to return to their original ministries.

Also, coming under the mission of the MOE will be the Nuclear Safety Investigation Committee (NSIC), a counciltype, third-party body associated with NRA. This organization is intended to ensure NRA's independence, to review objectively the NRA's effectiveness in regulatory actions and to investigate nuclear accidents.

At the nuclear industry level, the Federation of Electric Power Companies (FEPC) announced plans to launch an independent organization to promote improvement of safety in nuclear power plants. The mission of the new organization is to build a network among nuclear entities, including nuclear plant and fuel manufacturers in Japan. It aims to work toward nuclear safety improvements in close cooperation with domestic and international organizations. It is envisioned that nuclear utilities will have to abide by the recommendations made by the new organization. The FEPC regards such a mechanism as necessary for facilitating nuclear safety enhancements and knowledge.

\subsection{Nuclear Safety Regulation Reform}

Along with organizational restructuring, the ongoing reform embraces the introduction of new nuclear safety regulations and enhanced crisis management. One of the key concernssafety management-was addressed in the immediate aftermath of the disaster. In July 2011, NISA issued the Comprehensive Assessments for the Safety of Existing Power Reactor Facilities (NISA 2011). Also in July 2011, the Chief Cabinet Secretary, METI, and the Minister for the Restoration from and Prevention of Nuclear Accident issued a Confirmation of the Safety of Nuclear Power Stations in Japan. This document explained the procedure of Comprehensive Safety Assessments utilizing stress tests. The results of the assessments would be checked by NISA, after that they would be confirmed by the NSC. For the technical review of the

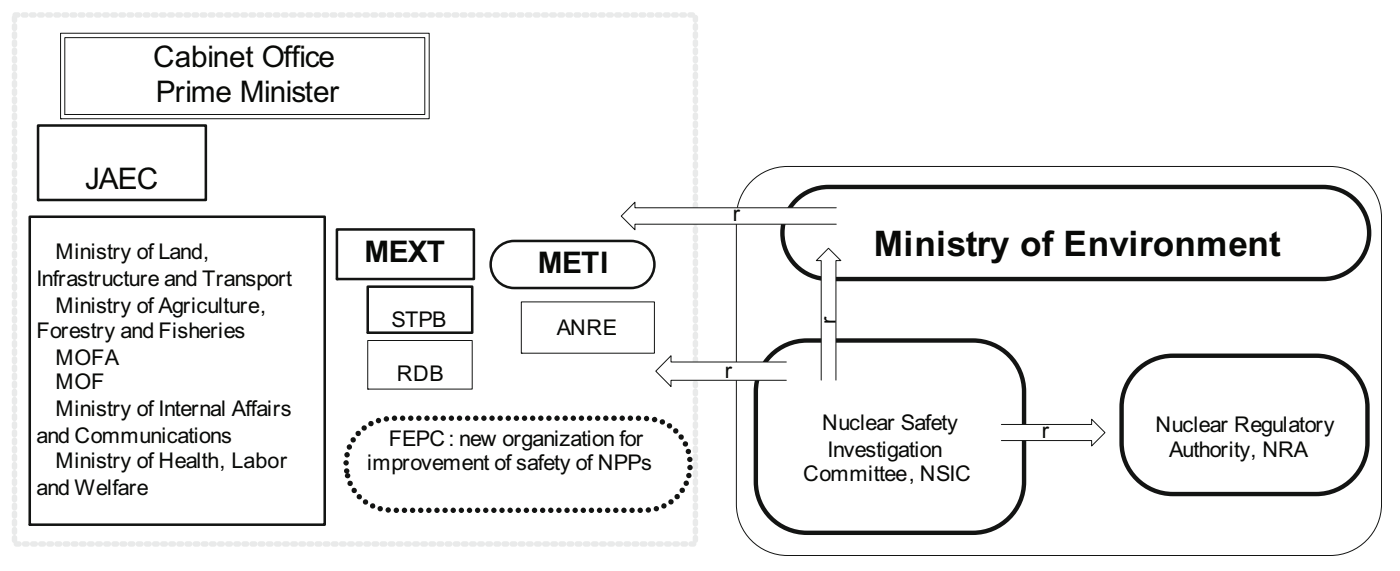

Figure 4. Adopted organization of nuclear energy regulation

Notes: "r" in arrows stands for "recommendations"; Rounded corner boxes signify changes envisioned. 
assessments, NISA received support from the Japanese Nuclear Energy Safety Organization (JNES). In January 2012, the International Atomic Energy Agency (IAEA) mission to Japan found the safety measures developed after March 2011 satisfactory (IAEA 2012).

In its December 2011 report (Cabinet Secretariat 2011), the Advisory Committee for Prevention of Nuclear Accident emphasized that the government should promote the reform of nuclear safety regulation based on the following principles: (1) separation of nuclear regulation and promotion; (2) integration of all nuclear regulation functions in one agency; (3) crisis management; (4) human resources development; (5) new safety regulations; (6) transparency; and (7) internationality. ${ }^{\mathrm{ix}}$

The documents adopted in 2012 (Table 1) emphasize the importance of safety measures.

Regulatory standards and criteria for nuclear facilities are revised to become stricter and accident management is required by law. So far, such measures have been provided by utilities on a voluntary basis. Now comprehensive risk assessment of the safety design and operation of each reactor is also required. The new regulations are based upon cutting-edge findings and the latest knowledge on safety-related matters developed at existing nuclear facilities. In principle, operation of power reactors will be limited to 40 years; a certain period of operational extension could be approved on a onetime-only basis. Under the new regulations, nuclear operators will take responsibility for constantly improving the safety of their facilities. In this context, implementation of necessary measures for nuclear disaster prevention will be stipulated. There will be quality assurance requirements for a nuclear facility, not only in the operational stage, but at its design and construction stages.

\section{Three Stages of Transition}

The post-Fukushima nuclear energy policy transformation has unfolded in a three-stage manner consistent with Jaeger's (2010) model of entry transitions into-emergency-exit transitions out, and involves what Hall explained as social learning. The first stage was rather tough for the government, as the Japanese public, united by a nation-wide tragedy, demanded a quick, efficient, and adequate response to all the sufferings the disaster brought. Most of the time, the government was unable to meet the public's expectations. The public's growing disappointment with the policy response was reflected in a deepening dissatisfaction with the government itself. Grassroots activity emerged across the country in an attempt to address the emergency, articulate people's concerns, and defend the desired future. After the emergency was (more or less) under control, the government set about a wide range of reforms.

The beginning of the second round was relatively smooth, as the public viewed positively the government's effort to compensate for the failures in the past. By the end of this round, however, when a choice between "yes" and "no" to nuclear energy became inevitable, policy actions began to be met with a mixed response. Commercially minded large businesses and nuclear dependant local entities favored reactor restarts, while a majority of the population, especially in the disaster hit areas, fiercely opposed the resumption. The second stage transformation embraced the organizational and legislative reforms needed to enhance nuclear safety management and reinforce institutional capacities for disaster prevention. These changes proved indispensable to the government to mitigate the continuing rather negative perception of the domestic nuclear industry (Pew Research Center 2012).

Table 1. Principal documents for nuclear safety regulation in Japan

\begin{tabular}{|c|c|c|}
\hline $\begin{array}{l}\text { Document } \\
\text { Reference No. }\end{array}$ & Title & Source \\
\hline Act No. 186 of 1955 & The Atomic Energy Basic Act & http://www.nsc.go.jp/NSCenglish/documents/laws/1.pdf \\
\hline $\begin{array}{l}\text { Act No. } 166 \text { of } \\
10 \text { June } 1957\end{array}$ & $\begin{array}{l}\text { The Law on the Regulation of Nuclear Source Material, } \\
\text { Nuclear Fuel Material and Reactors }\end{array}$ & http://www.nsc.go.jp/NSCenglish/documents/laws/3.pdf \\
\hline $\begin{array}{l}\text { Law No. } 162, \\
21 \text { May } 1958\end{array}$ & Law for Technical Standards of Radiation Hazards Prevention & http://www.nsc.go.jp/NSCenglish/documents/laws/4.pdf \\
\hline $\begin{array}{l}\text { Law No. } 147, \\
17 \text { June } 1961\end{array}$ & Law on Compensation for Nuclear Damage & http://www.nsc.go.jp/NSCenglish/documents/laws/5.pdf \\
\hline $\begin{array}{l}\text { Law No. } 223 \text {, } \\
15 \text { November } 1961\end{array}$ & Basic Law on Emergency Preparedness & http://www.nsc.go.jp/NSCenglish/documents/laws/7.pdf \\
\hline $\begin{array}{l}\text { Act No. } 170 \text { of } \\
11 \text { July } 1964\end{array}$ & The Electricity Business Act & $\begin{array}{l}\text { http://www.nisa.meti.go.jp/english/resources/legislativeframework/ } \\
\text { files/ElectricityBusiness.pdf }\end{array}$ \\
\hline May 1978 & $\begin{array}{l}\text { The Regulatory Guide for Reviewing Seismic Design of } \\
\text { Nuclear Power Reactor Facilities }\end{array}$ & http://www.nsc.go.jp/NSCenglish/guides/lwr/L-DS-I_02.pdf \\
\hline $\begin{array}{l}\text { Law No. } 156, \\
17 \text { December } 1999\end{array}$ & Special Law of Emergency Preparedness for Nuclear Disaster & http://www.nsc.go.jp/NSCenglish/documents/laws/8.pdf \\
\hline 12 March 2012 & $\begin{array}{l}\text { Measures against Severe Accidents at Light Water Nuclear } \\
\text { Power Reactor Facilities (Basic Policy on Ensuring Safety } \\
\text { against Tsunami beyond the Design Basis) }\end{array}$ & http://www.nsc.go.jp/NSCenglish/geje/20120312suggest_4.pdf \\
\hline 9 March 2012 & Strengthening of Japan's Nuclear Security Measures & http://www.aec.go.jp/jicst/NC/senmon/bougo/kettei120309.pdf \\
\hline
\end{tabular}


Although very important, these arrangements have been a tribute to the past, something that was established long before, was neglected, and imposed a very dear price on the entire nation. Despite the decision to restart the reactors in Fukui Prefecture (Box 5), this decision does not clarify the contour of long-term nuclear energy policy. Rather it signifies the beginning of the third stage of policy transformation.

\section{Box 5. 16 June 2012}

On 16 June 2012, the Japanese government approved the resumption of the Oi No. 3 and No. 4 reactors owned by KEPCO. After March 2011, reactors were methodically put off-line for a periodic check and on 5 May 2012 Japan stopped the last of its 50 operational nuclear reactors. The decision to restart was made on the grounds that the two Oi's reactors had passed their stress tests, the Japanese economy needed more electric power in the light of increasing demand during the summer, and the governor of Fukui Prefecture hosting the Oi NPP supported the move (The Japan Times 2012b). The decision took place amid public discontent, both domestic and international (Legewie 2012), and despite that a number of steps to improve the Oi NPP's safety have not been implemented yet: higher seawalls against tsunami and coastal levees are to be completed by March 2014, enhanced ventilation systems by March 2016, construction of an earthquakeresistant building to be used as an emergency operation center in the event of a major accident is intended by March 2016.

At this point the government needs a thorough approach to define, articulate, and communicate the long-term energy policy agenda (Prime Minister and His Cabinet 2012). In any scenario, the discussion of the future of nuclear energy in Japan will unfold across and overlap with an immense number of related issues, such as electricity market reform, the economics of renewable energy, climate change policy, and so on. Major organizational and regulatory reforms were planned for completion by April 2012, but because the issues of nuclear safety management and governance are so sensitive to the Japanese public, and because these issues define the structure of the Japanese economy in the long-run, they require careful deliberation and take longer than initially expected. The changes can be presented along several dimensions (Table 2).

On organizational reform, there are concerns about whether the new agency is not a mere nameplate change and window dressing. Such concerns are not groundless, because many of the new agency's staff members are likely to be transferees from NISA and NSC. It is important that the newly established body is free from the formerly exploited techniques and behavior patterns. Without a doubt, the new system faces a huge challenge to regain people's faith and demonstrate independence from the nuclear village in matters of nuclear safety and security. There are other reasons to question whether the ongoing reform is indeed comprehensive. It appears that some important functions have altogether elapsed during the centralization of regulatory responsibilities. That is to say, safety research, formerly a prerogative of the JAEC, and the inspections and other safeguards designed to prevent the diversion of nuclear material toward the production of nuclear weapons, previously among the duties of MEXT, have not been assigned to the jurisdiction of the new regulatory agencies.

A number of other nuclear safety concerns arise from the content of the latest amendments to the Atomic Energy Basic Act and the Nuclear Reactor Regulation Law. Despite heated debates continuing for over one year and very intense discussions held over the last decades about nuclear energy safety, bills drafted after the Fukushima disaster designate a 40-year lifespan for nuclear reactors and prescribe the implementation of "back-fit" measures that would help maintain the existing reactors up to the latest technological standards. But these bills also contained a staggering clause on "special exemptions" under which the reactors may be allowed to operate for up to 60 years. Analysis of the age structure of Japan's NPP reactors clarifies why such propositions have been made. Out of Japan's 54 reactors, four already have exceeded the 40-year limit. By 2030, 18 units, 39 percent of generating capacity (18,913 MW), will be older than 40 years and by 2050 all nuclear facilities will exceed the designated retirement cap (Japan Energy Economics Institute 2012).

Another key issue is the future of Japan's closed nuclear fuel cycle. This decision involves heavy trade-offs (Toki 2012). According to official estimates, it would cost 19 trillion yen (USD 245 billion) to reuse the waste reprocessed at Rokkasho over 40 years. Recycling all waste fuel would cost 2 yen per kilowatt hour in 2030, twice as much as just burying it in a final repository. Overall, the nonreprocessing option costs represent only one fourth to one third (4.2-6.1 trillion yen or USD 5.5-7.9 billion) of the reprocessing option (USD 24.7 billion). In September 2011, the JAEC estimated that Japan has 14,200 tons of spent fuel stored onsite at 17 facilities. Japan Nuclear Fuel Ltd.'s storage facilities are almost full and contain a total of 2,800 tons, as of February 2012. Several other NPPs are expected to reach maximum capacity over the next three years if their currently idled reactors are restarted. Meanwhile, Japan Nuclear Fuel's spent fuel reprocessing plant in Rokkasho, Aomori Prefecture, has been halted due to a series of accidents during tests undertaken since the project was launched nearly 20 years ago. In addition, the Monju FBR in Tsuruga, Fukui Prefecture, was idled for 14 years following a sodium leak in 1995, and has remained suspended since August 2010 because a 3.3-ton fuel exchange device plunged into it (The Japan Times 2012c; Podvig 2012). The JAEC changed its pre-Fukushima stance from total reprocessing to reprocessing and direct disposal of spent nuclear fuel if Japan's nuclear energy reliance is set at 15 percent. If nuclear power is completely eliminated by 2030, JAEC recommends burying all spent fuel.

Thus, the Japanese public has a number of concerns that have hardly been addressed by the government. The public is not satisfied with the government's poor delivery on the planning of the electric energy balance (Morita 2011). Instead of bare statements about the necessity for reactor restarts, the government is expected to provide detailed and reliable assessments of power supply and demand across the country. 
Table 2. Areas of energy policy transformation

\begin{tabular}{|c|c|c|}
\hline Policy Area & Policy before March 11 & Policy as of 24 June 2012 \\
\hline Nuclear safety & $\begin{array}{l}\text { 30-year licenses for new NPP plus unlimited 10-year } \\
\text { extensions; } \\
\text { No earthquake/tsunami stress tests; } \\
\text { NSC and METI in charge of safety regulation }\end{array}$ & $\begin{array}{l}\text { 40-year licenses for new NPP plus one possible } 20 \text {-year extension; } \\
\text { Mandatory earthquake/tsunami stress tests; } \\
\text { MOE in charge of safety regulation }\end{array}$ \\
\hline Nuclear power & $\begin{array}{l}54 \text { reactors, } 2 \text { under construction, } 12 \text { in the planning } \\
\text { process; } \\
\text { Increase of nuclear energy from } 30 \% \text { to } 50 \% \text { in } \\
\text { domestic electricity production by } 2030\end{array}$ & $\begin{array}{l}50 \text { commercial reactors, } 2 \text { of which are operational; no decision about } 2+12 \\
\text { reactors; } \\
\text { Decrease reliance on nuclear power under one of three scenarios: } 0 \%, 15 \% \text {, and } \\
20-25 \%\end{array}$ \\
\hline $\begin{array}{l}\text { Nuclear fuel } \\
\text { cycle }\end{array}$ & $\begin{array}{l}\text { Nuclear fuel chain / closed cycle; } \\
\text { Rokkasho reprocessing plant and Monju FBR }\end{array}$ & $\begin{array}{l}\text { Reprocessing policy to undergo change, depending on decision for nuclear power; } \\
\text { Monju budget cut by } 25 \% \text {; enrichment restarted on } 9 \text { March } 2012\end{array}$ \\
\hline Energy policy & $\begin{array}{l}\text { Nuclear energy is feasible means to improve energy } \\
\text { security; } \\
\text { Renewable discriminated (some support to photovol- } \\
\text { taic only, role of the New Energy and Industrial } \\
\text { Technology Development Organization, NEDO) }\end{array}$ & $\begin{array}{l}\text { Three pillars: energy best mix (renewable, photovoltaic, in particular), energy } \\
\text { efficiency, and safe nuclear; } \\
\text { Renewable energy law: feed-in tariff, law on procurement of renewable electric } \\
\text { energy; Domestic means to enhance energy security (domestic gas pipeline } \\
\text { system, test drilling off Niigata shore, etc.); } \\
\text { Reactivated resource diplomacy, in particular, with Russia (new LNG plant in } \\
\text { Vladivostok, gas pipeline to Wakkanai) }\end{array}$ \\
\hline
\end{tabular}

Only based on these estimates can the decision be made about how many reactors and which exact reactors need to be brought back into operation. The post-Fukushima reality does not look particularly bright for meaningful nuclear policy reform. It is exceedingly difficult to break the intimate relationship between cohesive state nuclear regulatory agencies and to succeed in preventing the vested interests from regaining control over the nuclear regulating agencies and creating institutional rigidities favoring the status quo. In Japan, there is no political consensus within the government, or even within any political party, on nuclear energy policy (Kiyonaga and Saito 2012), nor, as measured in opinion polls, is there social cohesion among the general public. Under these circumstances, the vested interests still look potent enough to counter the upbeat transition mood and deflect meaningful nuclear reforms.

\section{Conclusion}

Although the results of Japan's nuclear energy policy transition have yet to create widespread popular conviction that the new energy policy promotes the hallowed $3 \mathrm{E}$ formula (national energy security, economic security, and environmental security), the changes that have occurred are noticeable. Security, which formerly has been defined more in political economy terms, now clearly has absorbed considerations of safety. To achieve that result, the government revised its blueprints and prepared new policy frameworks, and the Diet drafted and enacted a number of new laws or amendments. These initiatives are intended to foster organizational, administrative, and regulative reforms for disaster risk governance and nuclear energy safety regulation. With regard to economic efficiency, previous rather blurred statements about the need to develop renewable energy and deregulate the domestic electric power market have advanced to the implementation stage, largely due to aggravated concerns about the cost and sufficiency of electric power supply (Ayoub and Yuji 2012, Moe 2012, Valentine 2011). A range of laws has been enacted recently on feed-in tariff (FIT), renewable portfolio standard (RPS), and power producer and supplier (PPS) system. Environmental aspects of energy policy are discussed, but these issues are often embedded within heated debates about the future of nuclear energy in Japan. At issue is whether an objective perspective on nuclear energy exists that includes environmental concerns. A frequently heard question, framed in many guises, asks: Is nuclear energy relatively clean ecologically, provided safety is ensured, or is it overwhelmingly dirty? The simple truth is that the Fukushima experience has ruined the long cherished Japanese myth of the absolute safety of nuclear energy, and a new consensus has yet to emerge.

At the outset of the nuclear energy era, all Japanese agreed that nuclear energy must be safe, nuclear energy governance must be democratic, and the results of nuclear policy conduct must be transparent. This article shows how these principles were followed in the past. Systematic violation of these fundamentals has become a routine of policy conduct that shaped the way Japan's nuclear energy industry dealt with the 2011 disaster. Diverse shifts in nuclear safety regulation and management have been initiated in the post-Fukushima period. Objectively, the progress made since March 2011 in various dimensions of Japan's energy policy is impressive. Despite the need for energy policy reform, which has been obvious for a long time, and despite some initial steps undertaken in that direction, the critical impulse for change was generated by an external force - the twin natural disaster and nuclear accident. It is important now that the Japanese government maintains the transition momentum so all feasible reforms can reinforce each other and create a genuinely comprehensive, coherent, and efficient new energy policy. 


\section{Notes}

i For more detail refer to section 3.3 of this article.

ii The term "creative destruction," also known as "Schumpeter's gale," is most associated with Schumpeter, who introduced it in a book Capitalism, Socialism and Democracy, originally published in 1942. Schumpeter explicitly derived the term form from Karl Marx's works and popularized it describing the disruptive process of transformation that accompanies economic innovations in business cycles.

iii This refers to purely nuclear energy research program, whilst research on nuclear weapons started during the WW II.

iv The amended Article 2 (approved by the Diet on 21 June 2012) reads, "The safe use of atomic power is aimed at contributing to the protection of the people's life, health and property, environmental conservation and national security." This wording, though, raised concerns about Japan's potential hawkish ambitions and is most likely to be amended shortly.

v In 2001, the Science and Technology Agency (STA) was merged with the Ministry of Education, Science, Sports and Culture to establish the MEXT.

vi The Japan Socialist Party, for instance, traditionally supports coal industry and opposes the rival nuclear power sector (Lesbirel 1998), while within the DPJ opinions are varying from Prime Minister Noda's rather moderate position to former Prime Minister Kan's ultimate renunciation of nuclear energy. For the LDP see Jupesta and Suwa (2012).

vii While a concise and direct translation is difficult, nigen taise symbolizes a government-business relationship wherein actors are involved in a complex interdependency characterized by internal conflict of interests and mutual mistrust.

viii Effective through September 2012, until the newly established nuclear regulatory authority starts functiong.

ix Clarifying an ambiguous wording of the principles (2) and (7). Principle (2) implies the consolidation and centralization of nuclear safety regulatory mandate in one newly designated nuclear safety regulatory authority, and principle (7) reflects Japan's willingness for a wide-range international cooperation on the matters of nuclear energy safety.

\section{References}

Aoki, M. 2010. Corporations in Evolving Diversity. Cognition, Governance and Institutions. New York: Oxford University Press.

Aoki, M., and G. Rothwell. 2011. Coordination under Large Uncertainty: An Analysis of the Fukushima Catastrophe. http://ssrn.com/ abstract $=1940207$.

Ayoub, N., and N. Yuji. 2012. Governmental Intervention Approaches to Promote Renewable Energies - Special Emphasis on Japanese Feed-in Tariff. Energy Policy 43 (2012): 191-201.

Cabinet Secretariat. 2011. Recommendation from Advisory Committee for Prevention of Nuclear Accident. http://www.cas.go.jp/jp/ genpatsujiko/info/teigen/recommendation.pdf.

Colignon, R. A., and C. Usui. 2003. Amakudari. The Hidden Fabric of Japan's Economy. New York: Cornell University Press.

DeWit, A. 2011a. Fallout From the Fukushima Shock: Japan's Emerging Energy Policy. The Asia-Pacific Journal 9 (45): No. 5.

_ 2011b. Japan's Nuclear Village Wages War on Renewable Energy and the Feed-in Tariff. The Asia-Pacific Journal. 08 December 2011. http://www.japanfocus.org/events/view/119.

DeWit, A., and M. Kaneko. 2011. Moving Out of the "Nuclear Village". In Tsunami: Japan's Post-Fukushima Future, edited by J. Kingston, 213-24. Washington, DC: Foreign Policy.

Fekete, A. 2011. Common Criteria for the Assessment of Critical Infrastructures. International Journal of Disaster Risk Science 2 (1): $15-24$.
Funabashi, Y., and K. Kitazawa. 2012. Fukushima in Review: A Complex Disaster, a Disastrous Response. Bulletin of the Atomic Scientists 68 (2): 9-21.

Hall, P. A. 1986. Governing the Economy. The Politics of the State Intervention in Britain and France. Cambridge: Polity Press.

1993. Policy Paradigms, Social Learning, and the State. The Case of Economic Policymaking in Britain. Comparative Politics 25 (3): $275-96$

IAEA (International Atomic Energy Agency). 2012. IAEA Mission to Review NISA's Approach to the "Comprehensive Assessments for the Safety of Existing Power Reactor Facilities" Preliminary Summary. http://www.iaea.org/newscenter/focus/fukushima/pre_report310112. pdf.

Ikeda, S., and T. Nagasaka. 2011. An Emergent Framework of Disaster Risk Governance towards Innovating Coping Capability for Reducing Disaster Risks in Local Communities. International Journal of Disaster Risk Science 2 (2): 1-9.

Ishibashi, K. 2007. Why Worry? Japan's Nuclear Plants at Grave Risk from Quake Damage. The Asia-Pacific Journal: Japan Focus. 11 August 2007. http://www.japanfocus.org/-Ishibashi-Katsuhiko/2495.

JAEC (Japan Atomic Energy Commission). 2009. White Paper on Energy (Enerugii hakusho). http://www.aec.go.jp/jicst/NC/about/ hakusho/hakusho2009/index.htm (in Japanese).

Jaeger, C. 2010. Risk, Rationality, and Resilience. International Journal of Disaster Risk Science 1 (1): 10-16.

JAIF (Japan Atomic Industrial Forum). 2012. Japanese Political Parties Begin Debate on New Nuclear Power Regulatory Organization in Lower House. http://www.jaif.or.jp/english/news_images/pdf/ ENGNEWS01 1338802034P.pdf.

Japan Energy Economics Institute. 2012. Japan Energy Brief No. 17, January 2012. http://eneken.ieej.or.jp/en/jeb/1201.pdf.

The Japan Times. 2012a. Nuclear Watchdog Autonomy. 14 May 2012. http://www.japantimes.co.jp/text/eo20120514a1.html.

2012b. Kansai Governors: Oi Reactors Restart is State's Call. 31 May 2012. http://www.japantimes.co.jp/text/nn20120531a3.html. . 2012c. Policy of Recycling All Spent Nuclear Fuel May Be Axed. 23 June2012.http://www.japantimes.co.jp/text/nn20120623a3. html.

Johnson, C. 1982. MITI and Japanese Miracle: The Growth of Industrial Policy. Stanford: Stanford University Press.

Jupesta, J., and A. Suwa. 2012. Sustainable Energy Policy in Japan Post Fukushima. IAEE Bulletin 2012 (4th Quarter): 23-26. International Association for Energy Economics.

Kanashima, H. 2012. Government Shows Plan for 15\% Power Cut in Kansai. The Yomiuri Shimbun. 16 May 2012. http://www.accessmy library.com/article-1G1-290494921/govt-shows-plan-15.html.

Kasperson, R. E. 2010. Science and Disaster Reduction. International Journal of Disaster Risk Science 1 (1): 3-9.

Kiyonaga, Y., and Y. Saito. 2012. Noda Shows Unyielding Stance on N-Reactors. The Yomiuri Shimbun. 10 June 2012. http://www. yomiuri.co.jp/dy/national/T120609003006.htm.

Kuhn, T. 1962. The Structure of Scientific Revolutions. Chicago: University of Chicago Press.

Legewie, J. 2012. For Better or Worse, Japan Might Remain Nuclear-Free Forever. The Japan Times. 21 May 2012. http://www. japantimes.co.jp/text/nb20120521ve.html.

Lesbirel, H. S. 1990. Implementing Nuclear Energy Policy in Japan. Top-Down and Bottom-Up Perspectives. Energy Policy 1990 (April): 267-81.

-1998. NIMBY Politics in Japan. Energy Siting and the Management of Environmental Conflict. Ithaca: Cornell University Press.

Lim, W.-K. 2011. Understanding Risk Governance: Introducing Sociological Neoinstitutionalism and Foucauldian Governmentality for Further Theorizing. International Journal of Disaster Risk Science 2(3): 11-20. 
Matanle, P. 2011. The Great East Japan Earthquake, Tsunami, and Nuclear Meltdown: towards the (Re)construction of a Safe, Sustainable, and Compassionate Society in Japan's Shrinking Regions. Local Environment 16 (9): 823-47.

Matsuo, Y., Y. Nagatomi, and T. Murakami. 2011. Thermal and Nuclear Generations Cost Estimates Using Corporate Financial Statements. Japan Energy Economics Institute. http://eneken.ieej.or.jp/data/4103. pdf.

METI (Ministry of Economy, Trade and Industry). 2008. Cool EarthInnovative Energy Technology Program. March 2008. http://www. meti.go.jp/english/newtopics/data/pdf/031320CoolEarth.pdf.

_. 2011. White Paper on Energy (Enerugii hakusho). http://www. enecho.meti.go.jp/topics/hakusho/2011/index.htm (in Japanese).

- 2012. Reform of Japan's Nuclear Safety Regulation. http:// www.cas.go.jp/jp/genpatsujiko/info/kokusaiws/siryo/reform_of_ regulation.pdf.

Minoura, K., and S. Nakaya. 1991. Traces of Tsunami Preserved in Inter-Tidal Lacustrine and Marsh Deposits: Some Examples from Northeast Japan. Journal of Geology 99 (2). http://www.jstor.org/ pss $/ 30081120$.

Moe, E. 2007. Governance, Growth and Global Leadership: The Rise of the State in Technological Progress. Aldershot and Burlinton: Ashgate.

- 2012. Vested Interests, Energy Efficiency and Renewable in Japan. Energy Policy 40: 260-73. http://www.sciencedirect.com/ science/journal/03014215/40.

Morita, Y. 2011. Japan's Issues and Concerns on Energy Supply and Demand after the Great East Japan Earthquake. Report. Japan Institute of Energy Economics. http://www.pecj.or.jp/japanese/overseas/ conference/pdf/conference08-07.pdf.

Nagata, K. 2012. Further Restarts Hinge on New Watchdog. The Japan Times.17June2012.http://www.japantimes.co.jp/text/nn20120617b4. html.

The National Government Organization Law. Law No. 120. 1948. http://www.kantei.go.jp/foreign/constitution_and_government/the national_goverment_low.html.

National Policy Unit. 2011. Strategy for Rebirth of Japan. http://www. npu.go.jp/policy/pdf/20120127/20120127_en1.pdf.

NISA (Nuclear and Industrial Safety Agency). 2011. Comprehensive Assessments for the Safety of Existing Power Reactor Facilities. http://www.nisa.meti.go.jp/english/press/2011/08/en20110831-2-1.pdf.

Norio, O., T. Ye, Y. Kajitani, P. J. Shi, and H. Tatano. 2011. The 2011 Eastern Japan Great Earthquake Disaster: Overview and Comments. International Journal of Disaster Risk Science 2 (1): 34-42.

Nuclear Safety Commission. 1955. Atomic Energy Basic Act. Act No. 186. http://www.nsc.go.jp/NSCenglish/documents/laws/1.pdf.

Olson, M. 1982. The Rise and Decline of Nations. London: Yale University Press.

Onitsuka, H. 2012. Hooked on Nuclear Power: Japanese State-Local Relations and the Vicious Cycle of Nuclear Dependence. The
Asia-Pacific Journal: Japan Focus. http://www.japanfocus.org/Hiroshi-Onitsuka/3676\#.

Pew Research Center. 2012. Disaster Weakened Nation. http://www. pewglobal.org/2012/06/05/japanese-wary-of-nuclear-energy/.

Podvig, P. 2012. Japanese Mislead About Spent Fuel Reprocessing Costs. IPFM Blog. http://fissilematerials.org/blog/2012/01/japanese_ mislead_about_sp.html.

Prime Minister and His Cabinet. 2012. Press Conference by Prime Minister Yoshihiko Noda, 8 June 2012. http://www.kantei.go.jp/foreign/ noda/statement/201206/08kaiken_e.html.

Samuels, R. J. 1987. The Business of Japanese State: Energy Markets in Comparative and Historical Perspectives. Ithaca: Cornel University Press.

Schumpeter, J. A. 1983. The Theory of Economic Development. New Brunswick and London: Transaction Books.

Sciubba, E. 2011. Fukushima: There Are Lessons to Be Learnt, on Both Sides. Energies 4 (5): 818-25.

Shi, P. J., N. Li, Q. Ye, W. J. Dong, G. Y. Han, and W. H. Fang. 2010. Research on Integrated Disaster Risk Governance in the Context of Global Environmental Change. International Journal of Disaster Risk Science 1 (1): 17-23.

Toki, M. 2012. Fukushima's Impact on Japan's Nuclear Fuel Cycle Policy. James Martin Center for Nonproliferation Studies. http:// wmdjunction.com/120309_fukushima_japan_nuclear.htm.

Valentine, S. V. 2011. Japanese Wind Energy Development Policy: Grand Plan or Group Think? Energy Policy 39 (11): 6842-54.

Wang, Q., and X. Chen. 2012. Regulatory Failures for Nuclear SafetyThe Bad Example of Japan-Implication for the Rest of World. Renewable and Sustainable Energy Reviews 16: 2610-17.

Yergin, D., and J. Stanislaw. 2002. The Commanding Heights. New York, London, Toronto, Sydney: Free Press.

The Yomiuri Shimbun. 2011. Nuclear Crisis: How it Happened. "Nuclear Power Village" a Cozy, Closed Community. 16 June 2011. http:// www.yomiuri.co.jp/dy/national/T110615005652.htm.

Yoshioka, H. 1999. Technology versus Commercial Feasibility: Nuclear Power and Electric Utilities. In Science, Technology and Society in Contemporary Japan, edited by M. Low, S. Nakayama, and H. Yoshioka, 66-81. Cambridge: Cambridge University Press.

2005. Forming a Nuclear Regime and Introducing Commercial Reactors, and Nuclear Power Research and the Scientists' Role. In $A$ Social History of Science and Technology in Contemporary Japan: Road to Self-Reliance, 1952-1959, edited by S. Nakayama, K. Gotō, and H. Yoshioka, 80-143. Melbourne: Trans Pacific Press.

. 2006. Future Plans for Nuclear Physics Research, The Rise of Nuclear Fusion Research, The Development and Utilization of Nuclear Reactors. In A Social History of Science and Technology in Contemporary Japan: High Economic Growth Period, 1960-1969, edited by S. Nakayama and H. Yoshioka, 189-273. Melbourne: Trans Pacific Press.

Open Access This article is distributed under the terms of the Creative Commons Attribution License which permits any use, distribution, and reproduction in any medium, provided the original author(s) and source are credited. 